\title{
Dialogue and coexistence of religions and belief centers in Kurdistan
}

\author{
J. F. Ali ${ }^{1}$ \& O. Hassan ${ }^{2}$ \\ ${ }^{1}$ Presidency of Koya University, Kurdistan, Iraq \\ ${ }^{2}$ Faculty of Education, Koya University, Kurdistan, Iraq
}

\begin{abstract}
Life means innovation, and innovation is architecture, roads and city; in other words, coexistence. This project which is for establishing a dialogue center for coexistence amongst followers of different belief systems in Kurdistan is one of the necessities of harmony and peace especially in Koya city which has been a leading example of coexistence between Muslims, Christians and Jews besides some different branches of these main religions.

This project is scientific, social and religious; it will help in building a brotherly joint life amongst religious denominations of Koya and Kurdistan so that more development will occur.

This project consists of four pages, which explains the reasons of establishment, essential systems, address, definition, and general guidelines of this center; the main goals, activities, budget and the structure of this center are also clarified. The execution of this project serves a great cause to this city and brings back its historical image and role in coexistence.
\end{abstract}

\section{Introduction}

Urban development and innovation is the best and most realistic mirror that can represent history and social situation of a society, from this perspective the effects of urban development that is dependent on the coexistence and harmony of belief systems' followers can be analyzed. Kurdistan is a multi-religion, multination region that has achieved coexistence and acceptance of each other, from the perspective of translating this idea for urban development, and attempting for glorifying all religious holy places and serving temples belonging to all religious groups equally. 
Koya is one of the ancient cities of Kurdistan that has been a home for followers of Islam, Christianity, Judaism, etc., for hundreds of years.

For this city to continue holding the message of love and goodwill amongst all religions, a center for religious dialogue and conversation is needed. Especially in Koya city, so that Koya becomes the center of understanding amongst the holders of that message. This will reflect not only the city's architectural character but its physical, local and general character as well. Thus, companies and rich people can fearlessly invest in Koya city, which eventually leads to development of Koya city [1, 2].

Many researchers and religious people have identified a significant impact on local communities and successful societies. Therefore, Kurdistan region in particular is an ideal place for this activity, as it has been recognized as religious coexistence from ancient history in the East and internally people have coexisted. To continuously improve and develop this spirit for goodwill through improving a civilized society in Kurdistan, the idea of establishing the dialogue center was put forward from Koya University.

\section{The background}

The idea of this legal, social and legitimate-project has been articulated in minds of the two researchers for the excessive necessity of a center for dialogue, conversation and coexistence amongst all holy religions and belief systems that have existed in Kurdistan and Koya from an ancient history. It is obvious to the reader that most of current political and social issues are tied up to difference in religious beliefs and thinking. Moreover, it could be argued that most of the tensions and struggles of our time is directly connected to religion or belief systems. Because there are tens of different religions and religious groups in Kurdistan that has caused a direct negative impact on innovation, thus the researchers find it essential to establish a scientific center in Kurdistan especially in Koya city - for dialogue and conversation amongst all religions and doctrines followers in Kurdistan. Accordingly, Kurdish society is protected from any potential religious and/or social issues that could happen amongst the followers of those religions existing in Kurdistan and Koya. Thus, this project provides peaceful attempts for establishing harmony and understandings amongst different religious groups in Kurdistan, it also fights the obstacles that prevent the religious minorities and majorities to communicate and establish an understanding of each other.

The structure of the center can consist of the advisory committee, which consists of a number of religious and doctrinal personnel from different belief systems in Kurdistan and academic social personnel, selected from a conference that is held every four years with the help of Koya University. The committee can make decisions about creating annual planning for budget of the center and electing administrative committee members. 


\section{Reasons of establishment}

After the falling of previous dictator regime in Iraq, the lack of a civilized society and organization created a fearful gap in the entire country, which created several obstacles amongst the political process in Iraq. The situation caused dramatic increase of affiliation towards religious denomination, dogma and doctrines in a narrow-minded manner. Consequently a form of social division was occurred which further led to a series of deadly events.

As it was pointed out earlier that Kurdistan in general and Koya in particular holds followers of tens of religions, and the possibility of clash between holders of those religions is always real especially in the current circumstances of our surrounding countries - Iraq, Syria, Turkey, Saudi, etc [3]. Obviously, religious problems exist in all four sides of our country, thus we need to protect our immunity.

For the same reasons of poor civil society in Kurdistan the preliminary indications of this scary situation are beginning to appear. From this point, the necessity of this center becomes obvious. It is a hope that this project is given serious considerations for preventing any sort of violence and religious misunderstanding amongst different groups in Kurdistan. There should be continuous attempts for getting the groups closer and get them to accept each other through dialogue and discussions.

The dialogue and religious coexistence center in Kurdistan is an academic scientific social organization that improves cohabitation amongst different religions and their branches through dialogue, research, seminars and scientific conferences.

This center governs its activities in the boundary of legal, legitimate and high social values of Kurdistan nation and abides by the equality and justice values. The center will be located in Koya city inside Koya University campus and further branches could be opened in Kurdistan by the cooperation of the University and other civil organizations.

Publishing dialogue articles for peace, innovation and cohabitation amongst different religions and their branches in Kurdistan can identify the aims of this center. Supporting the distribution of acceptance between the Muslim majority and other religions and denominations in Kurdistan, like Christians, Yezidi and Kakay, etc.

Attempts to purify culture, customs and traditions in Kurdistan from the remains of killing, bloodshed, religious hatred and malevolence under any circumstance or justification [4].

Attempt to achieve stimulation that prevents individual and groups belonging to any religion or doctrine from using religious laws as alternatives to court and laws for punishing Kurdistan citizens.

Attempt to accomplish civil rights and freedom for Religious minorities in Kurdistan, especially for those who have fear to extinct.

Attempt to work for glorifying all religious holy places and serving the temples of all religions and doctrines equally $[5,6]$. 


\section{Dialogue center activities}

The tasks of the center can be improved and increased by interaction with the society's issues and needs; however as a principle the center will focus on [7]:

- Holding national and international conferences in Kurdistan, to represent all religious followers for exchanging honest ideas and doing all that is necessary for building a communication bridge, meanwhile to present academic research topics relating to religion and religious people and their cohabitation in Kurdistan.

- Visiting and inviting religious scholars from all parts and providing opportunities for meeting and discussions.

- Holding joint symposiums, TV and journal programs amongst representatives and religious scholars from all different belief systems in Kurdistan and presenting thoughts, ideas, criticism and complaints frankly.

- Cooperation with media for reiterating the message of peace and coexistence amongst all religions and doctrines followers in Kurdistan and preventing the growth of racist, hatred and violence using a transparent and constructive approach.

- Helping authorities in solving the problems created by some individual or groups like insulting religion or religious affiliation of Kurdistan residents, or attempt to deprive them from their civil right [8].

- Work with religious organizations not to use temples for circulating religious hatred and violence [8].

- Attempts would be carried out to refund those who have been mistreated for reasons of religious identity.

- Working to accomplish harmony amongst the followers of all religions without differentiating their representatives in this center.

\section{Conclusions}

Social capital is the result of trust, social networks, and social health, and it encourages social and economic opportunities for local communities. Therefore, contributions to community, such as volunteer work, mental and physical health, and increased education and civic awareness and social networks are all the components of the social capital concept of the religious education. In general, the dialogue center can give various positive effects on communities, ranging from increased confidence, improve mental and physical health, low crime, and enhance the levels of volunteer work and community outreach.

\section{References}

[1] Abu Abdallah, Y., Countries Dictionary, Beirut: House of Thought. (The reference is originally in Arabic.)

[2] Al-Samook, S. M., and Elyan, R. (1982), Comparative religions, Baghdad publishing house. (The reference is originally in Arabic.) 
[3] Al-Hanun, R. (2005), Religions and Doctrines in Iraq, 1st edition. (The reference is originally in Arabic.)

[4] Egypt, M. o. (n.d.), Islamic Concepts, Retrieved from Islamic Council, http://islamiccouncil.com

[5] Religion in Islamic term (n.d.): Retrieved from Al-Islam: http://www.alislam.com

[6] Abu Ainain, B. (1983): Social Relationship between Muslims and NonMuslims, Baghdad: Arabic Renaissance House. (The reference is originally in Arabic.)

[7] Kurdistan, P. U. (2001), Rules of Procedure (Democratic organizations), Sulaymanyah.

[8] Aswad, A. a.: Entrance to the Study of Religions and Doctrines. Beirut: Arabic House for Encyclopedias. (The reference is originally in Arabic.) 